\title{
Relation of measured basal temperatures and the spatial distribution of the geothermal heat flux for the Greenland ice sheet
}

\author{
Ralf GREVE \\ Institute of Low Temperature Science, Hokkaido University, Sapporo 060-0819, Japan \\ E-mail: greve@lowtem.hokudai.ac.jp
}

\begin{abstract}
The thermomechanical, three-dimensional ice-sheet model SICOPOLIS is applied to the Greenland ice sheet. Simulations over two glacial-interglacial cycles are carried out, driven by a climatic forcing interpolated between present conditions and Last Glacial Maximum anomalies. Based on the global heat-flow representation by Pollack and others (1993), we attempt to constrain the spatial pattern of the geothermal heat flux by comparing simulation results to direct measurements of basal temperatures at the GRIP, NorthGRIP, Camp Century and Dye 3 ice-core locations. The obtained heatflux map shows an increasing trend from west to east, a high-heat-flux anomaly around NorthGRIP with values up to $135 \mathrm{~mW} \mathrm{~m}^{-2}$ and a low-heat-flux anomaly around Dye 3 with values down to $20 \mathrm{~mW} \mathrm{~m}^{-2}$. Validation is provided by the generally good fit between observed and measured ice thicknesses. Residual discrepancies are most likely due to deficiencies of the input precipitation rate and further variability of the geothermal heat flux not captured here.
\end{abstract}

\section{INTRODUCTION}

The Greenland ice sheet is the second-largest present-day ice mass on Earth. While its surface (Fig. 1) and basal topographies are known very accurately (Bamber and others, $2001 \mathrm{a}, \mathrm{b}, \mathrm{c})$, and surface velocity measurements are available all around the $2000 \mathrm{~m}$ elevation contour (Thomas and others 1998; see also nsidc.org/data/parca) and at several other locations, direct information on the thermodynamic state of the ice sheet is limited to a small number of deep ice cores. For the past, apart from limited data on ice extent since the Last Glacial Maximum (LGM) at approximately $21 \mathrm{kyr}$ BP, information on the dynamics and thermodynamics of the Greenland ice sheet can only be obtained from flow models.

A number of studies on the Greenland ice sheet over the last glacial-interglacial cycles have been conducted with three-dimensional thermomechanical ice-sheet models (Letréguilly and others, 1991; Calov and Hutter, 1996; Ritz and others, 1997; Greve and others, 1998, 1999; Van de Wal, 1999; Marshall and Cuffey, 2000; Huybrechts, 2002; Tarasov and Peltier, 2003). These models have in common that they solve the equations of the shallow-ice approximation (Hutter, 1983; Morland, 1984). Climate forcing is provided based on the present distributions of precipitation/accumulation and surface history, modified by timedependent offsets derived from ice-core isotope records $\left(\delta^{18} \mathrm{O}, \delta \mathrm{D}\right)$. Except for the study by Tarasov and Peltier (2003), the geothermal heat flux, which enters the ice body from below and provides the lower boundary condition for the temperature field in the ice, is assumed to be spatially and temporally constant, with values in the range 42$65 \mathrm{~mW} \mathrm{~m}^{-2}$. As demonstrated by Greve and Hutter (1995), this input quantity plays a crucial role for the modelled basal temperature, surface topography and ice-flow velocities, and deserves further attention.

Therefore, in this study we attempt to constrain the spatial distribution of the geothermal heat flux with the available temperature data of four deep ice cores: the Greenland Icecore Project (GRIP), North Greenland Icecore Project (NorthGRIP), Camp Century and Dye 3 cores (Fig. 1). In section 2, the main features of the thermomechanical icesheet model SICOPOLIS are described. In section 3, a climatic forcing for the last glacial-interglacial cycles is introduced, which goes beyond previous approaches by interpolating the precipitation and surface-temperature patterns between present conditions and LGM anomalies provided by a general circulation model (GCM). Section 4 describes the general set-up of transient simulations from 250 kyrBP until today, covering two entire glacial-interglacial cycles. In section 5, four simulations with different assumptions for the geothermal heat flux are discussed. It is demonstrated that with a pattern, based on the global heatflow representation by Pollack and others (1993) and modified with suitable values at the ice-core locations mentioned above, the basal temperatures can be matched accurately.

\section{THERMOMECHANICAL ICE-SHEET MODEL SICOPOLIS}

The model SICOPOLIS (SImulation COde for POLythermal Ice Sheets) simulates the large-scale dynamics and thermodynamics (ice extent, thickness, velocity, temperature, water content and age) of ice sheets three-dimensionally and as a function of time (Greve, 1997). It is based on the shallow-ice approximation (Hutter, 1983; Morland, 1984) and the rheology of an incompressible, heat-conducting, powerlaw fluid (Glen's flow law; see Paterson, 1994). The thermomechanical coupling is described by the temperature- and water-content-dependent rate factor in the form of Greve and others (1998) which follows Paterson's (1994) recommendations. Isostatic depression and rebound of the lithosphere due to changing ice load is modelled by the local-lithosphere-relaxing-asthenosphere (LLRA) approach with an isostatic time lag $\tau_{\text {iso }}$ (Le Meur and Huybrechts, 1996; Greve, 2001).

A particular feature of the model thermodynamics is the distinction between cold ice with a temperature below the pressure-melting point and temperate ice with a temperature at the pressure-melting point. The interface that separates 


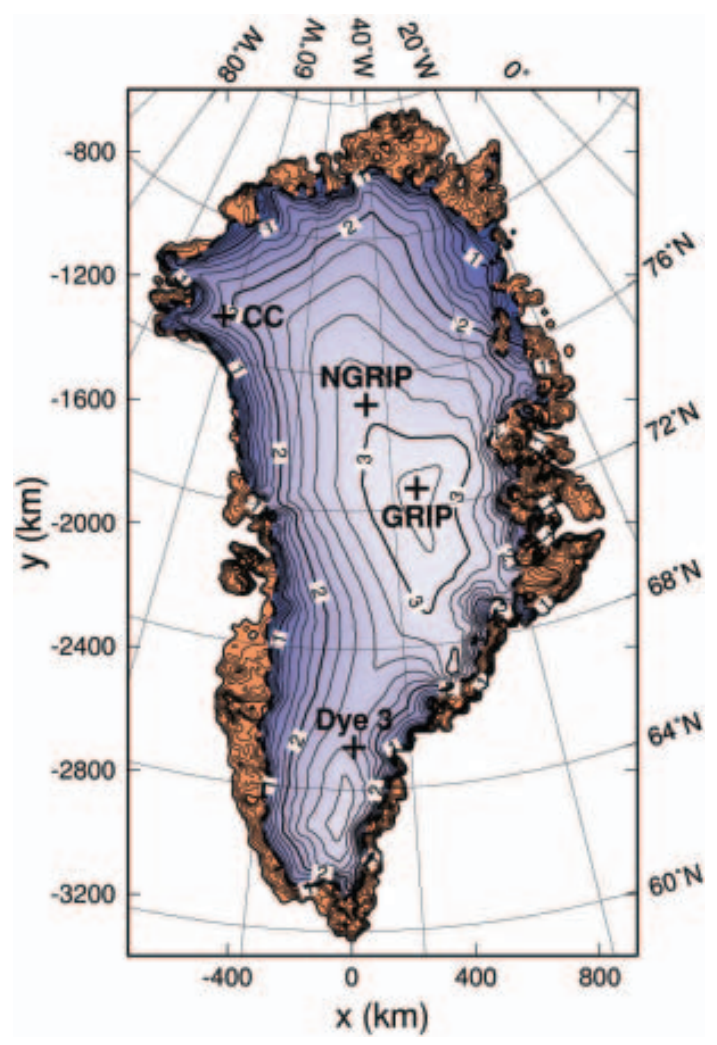

Fig. 1. Surface topography of the Greenland ice sheet, by Bamber and others $(2001 \mathrm{~b}, \mathrm{c})$. Contour spacing is $200 \mathrm{~m}$; labels are in km a.s.l. The GRIP, NorthGRIP (NGRIP), Camp Century (CC) and Dye 3 ice-core locations are indicated. Brown areas mark ice-free land.

cold and temperate ice is monitored using Stefan-type energy-flux and mass-flux matching conditions. In the cold ice, which makes up by far the larger part of the volume of an ice sheet, the temperature evolution is computed from the three-dimensional energy balance which includes horizontal and vertical advection, vertical heat conduction and dissipative strain heating. By contrast, in the temperate ice, which can exist as thin layers overlying a temperate base, the energy balance provides an evolution equation for the water content which comprises horizontal and vertical advection, melting due to dissipation and downward water drainage. The thermal inertia of the lithosphere is accounted for by solving the vertical heat-conduction equation in a $5 \mathrm{~km}$ thick thermal boundary layer below the ice. The set of evolution equations is listed in the study by Greve and others (1998).

Basal sliding is described by a Weertman-type sliding law in the form of Greve and others (1998), modified to allow for sub-melt sliding as proposed by Hindmarsh and Le Meur (2001):

$$
\vec{v}_{\mathrm{b}}\left(T_{\mathrm{b}}^{\prime}\right)=-\frac{C_{\mathrm{b}}\left(T_{\mathrm{b}}^{\prime}\right)}{\rho g} \frac{|\vec{\tau}|^{p-1}}{P^{q}} \vec{\tau},
$$

where $\vec{v}_{\mathrm{b}}$ is the basal-sliding velocity, $\vec{\tau}$ the basal shear traction in the bed plane, $\rho$ the ice density, $g$ the gravity acceleration and $P=\rho g H$ the overburden pressure. The stress and pressure exponents are chosen as $p=3$ and $q=2$. The sliding coefficient $C_{\mathrm{b}}$ depends on the homologous temperature $T_{b}^{\prime}$ (temperature relative to pressure melting, in ${ }^{\circ} \mathrm{C}$ ) via
Table 1. Standard physical parameters of the ice-sheet model SICOPOLIS

\begin{tabular}{|c|c|}
\hline Quantity & Value \\
\hline Gravity acceleration, $g$ & $9.81 \mathrm{~m} \mathrm{~s}^{-2}$ \\
\hline Density of ice, $\rho$ & $910 \mathrm{~kg} \mathrm{~m}^{-3}$ \\
\hline Power-law exponent, $n$ & 3 \\
\hline Flow enhancement factor, $E$ & $1 / 3^{\star}$ \\
\hline Melting point at atmospheric pressure, $T_{0}$ & $273.15 \mathrm{~K}$ \\
\hline Heat conductivity of ice, $\kappa$ & $9.828 \mathrm{e}^{-0.0057 T[K]} \mathrm{W} \mathrm{m} \mathrm{K}^{-1}$ \\
\hline Specific heat of ice, $c$ & $(146.3+7.253 T[\mathrm{~K}]) \mathrm{J} \mathrm{kg}^{-1} \mathrm{~K}^{-1}$ \\
\hline Latent heat of ice, $L$ & $335 \mathrm{~kJ} \mathrm{~kg}^{-1}$ \\
\hline Clausius-Clapeyron gradient, $\beta$ & $8.7 \times 10^{-4} \mathrm{Km}^{-1}$ \\
\hline Isostatic time lag, $\tau_{\text {iso }}$ & 3000 years \\
\hline Asthenosphere density, $\rho_{\mathrm{a}}$ & $3300 \mathrm{~kg} \mathrm{~m}^{-3}$ \\
\hline $\begin{array}{l}\text { Density } \times \text { specific heat of the } \\
\text { lithosphere, } \rho_{r} c_{r}\end{array}$ & $2000 \mathrm{~kJ} \mathrm{~m}^{-3} \mathrm{~K}^{-1}$ \\
\hline Heat conductivity of the lithosphere, $\kappa_{r}$ & $3 \mathrm{~W} \mathrm{~m}^{-1} \mathrm{~K}^{-1}$ \\
\hline
\end{tabular}

${ }^{\star} E=1$ for Holocene or Eemian ice (deposited between $11 \mathrm{kyr} \mathrm{BP}$ and the present, or between 132 and $114.5 \mathrm{kyr} B \mathrm{P}), E=3$ for Weichselian or preEemian ice (deposited during other times).

$$
C_{\mathrm{b}}=C_{\mathrm{b}}^{0} \mathrm{e}^{T^{\prime}{ }_{b} / \gamma}
$$

(note that $T_{\mathrm{b}}^{\prime} \leq 0^{\circ} \mathrm{C}$ ), where $C_{\mathrm{b}}^{0}=10^{5} \mathrm{a}^{-1}$ is the sliding coefficient at the pressure-melting point, and the constant $\gamma$ is set to $\gamma=1^{\circ} \mathrm{C}$. In case of a temperate base $\left(T_{b}^{\prime}=0^{\circ} \mathrm{C}\right)$, basal melting is computed by balancing the heat fluxes from the ice and the lithosphere and the heat production due to basal sliding $\left(\vec{v}_{\mathrm{b}} \cdot \vec{\tau}\right)$.

External forcing is specified by (i) the mean annual air temperature at the ice surface, (ii) the surface mass balance (accumulation, ablation), (iii) the global sea level which defines the land area available for glaciation, and (iv) the geothermal heat flux prescribed at the bottom of the lithospheric thermal boundary layer. All computations are carried out in a stereographic plane with standard parallel at $71^{\circ} \mathrm{N}$, spanned by the Cartesian coordinates $x$ and $y$. The vertical coordinate $z$ is taken positive upward, and the zero level is the present-day reference geoid. The distortions due to the stereographic projection are corrected by appropriate metric coefficients.

The standard values of the relevant physical parameters used for the simulations herein are listed in Table 1.

\section{CLIMATIC FORCING}

As measure for the climate state at any time $t$, a glacial index $g(t)$ is defined such that $g=1$ denotes LGM conditions and $g=0$ present conditions (Forsström and others, 2003; Forsström and Greve, 2004). It is based on the GRIP surface temperature $\left(T_{\mathrm{s}}\right)$ history derived from the $\delta^{18} \mathrm{O}$ record (Dansgaard and others, 1993) with the quadratic conversion formula found by Johnsen and others (1995),

$$
g(t)=\frac{T_{\mathrm{s}}(t)-T_{\mathrm{s}, \text { present }}}{T_{\mathrm{s}, \mathrm{LGM}}-T_{\mathrm{s}, \text { present }}}
$$

The reference values are $T_{\mathrm{s} \text {, present }}=-31.74^{\circ} \mathrm{C}$ (for $\delta^{18} \mathrm{O}=$ $-35.2 \%$ ) and $T_{\mathrm{s}, \mathrm{LGM}}=-55.15^{\circ} \mathrm{C}$ (for $\delta^{18} \mathrm{O}=-42.71 \%$ ), where the latter represents the LGM minimum taken at 21.9 kyr BP. 

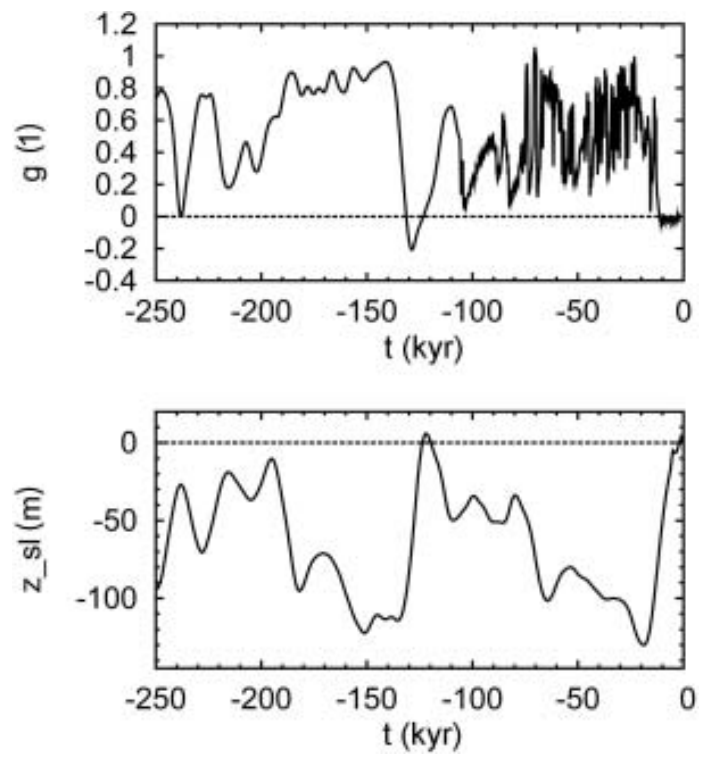

Fig. 2. (a) Glacial index $g(t)$ derived from the GRIP and Vostok surface temperature records (Dansgaard and others, 1993; Johnsen and others, 1995; Petit and others, 1999). (b) Sea-level history $z_{\mathrm{sl}}(t)$ derived from the SPECMAP marine $\delta^{18} \mathrm{O}$ record (Imbrie and others, 1984).

Prior to $105 \mathrm{kyr} B$, the GRIP record is believed to be falsified due to ice-flow irregularities (North Greenland Ice Core Project members, 2004), and for that period the glacial index is derived from the surface-temperature history based on the $\delta \mathrm{D}$ record of the Antarctic Vostok ice core (Petit and others, 1999) instead. In order to smooth out rapid climate oscillations which are unlikely to be in phase between Greenland and Antarctica, the Vostok record is subjected to a Gaussian filter with $2 \mathrm{kyr}$ filter width. The resulting glacial index is shown in Figure 2a for the period from $250 \mathrm{kyr} B \mathrm{P}$ until today. Similar synthetic blends of these two ice-core records have been used by Marshall and Cuffey (2000) and Huybrechts (2002).

This glacial index is used to determine the surfacetemperature and precipitation distribution over the ice sheet by interpolating between present and LGM conditions. The present-day surface air temperature is parameterized as a function of surface elevation, $h$, and latitude, $\phi$, following Ritz and others (1997):

$$
\begin{aligned}
T_{\text {ma, present }}\left[{ }^{\circ} \mathrm{C}\right] & =49.13-0.7576 \phi\left[{ }^{\circ} \mathrm{N}\right]+\gamma_{\mathrm{ma}} h, \\
T_{\mathrm{mj}, \text { present }}\left[{ }^{\circ} \mathrm{C}\right] & =30.38-0.3262 \phi\left[{ }^{\circ} \mathrm{N}\right]+\gamma_{\mathrm{mj}} h,
\end{aligned}
$$

where $T_{\mathrm{ma}}$ and $T_{\mathrm{mj}}$ are the mean annual and mean July (summer) surface temperatures, respectively, and the lapse

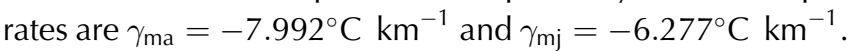
The present precipitation map, $P_{\text {ma, present }}(\lambda, \phi)$ (the index 'ma' stands for 'mean annual', $\lambda$ denotes longitude and $\phi$ latitude), is constructed based on the digitized accumulation map by Calanca and others (2000), complemented by Jaeger's (1976) global precipitation map in the regions not covered by the Calanca and others (2000) data.

For the LGM counterparts of these climatic input fields, results of GCM simulations with the UKMO model (Hewitt and Mitchell 1997), carried out for the Paleoclimate Modelling Intercomparison Project (PMIP; see www-Isce. cea.fr/pmip), are utilized. The coarse model output
(2.5 $5^{\circ}$ long. $\times 2.5^{\circ}$ lat. $)$ is interpolated to the finer SICOPOLIS grid with inverse-distance weighing. In order to largely eliminate systematic errors of these simulations, anomalies with respect to present-day conditions (denoted by the hat symbols) are defined,

$$
\begin{aligned}
& \widehat{T}_{\text {ma }}(\lambda, \phi) \\
& \quad=T_{\text {ma, LGM }}^{\mathrm{UKMO}}(\lambda, \phi)-T_{\text {ma, present }}^{\mathrm{UKMO}}(\lambda, \phi)-\gamma_{\mathrm{ma}}\left(h_{\mathrm{LGM}}^{\mathrm{UKMO}}-h_{\text {present }}^{\mathrm{UKMO}}\right), \\
& \widehat{T}_{\mathrm{mj}}(\lambda, \phi) \\
& \quad=T_{\mathrm{mj}, \mathrm{LGM}}^{\mathrm{UKMO}}(\lambda, \phi)-T_{\mathrm{mj}, \text { present }}^{\mathrm{UKMO}}(\lambda, \phi)-\gamma_{\mathrm{mj}}\left(h_{\mathrm{LGM}}^{\mathrm{UKMO}}-h_{\text {present }}^{\mathrm{UKMO}}\right), \\
& \widehat{P}_{\text {ma }}(\lambda, \phi)=P_{\text {ma, LGM }}^{\mathrm{UKMO}}(\lambda, \phi) / P_{\text {ma, present }}^{\mathrm{UKMO}}(\lambda, \phi) .
\end{aligned}
$$

Note that the temperature anomalies are differences, whereas the precipitation anomaly is defined as a ratio. In the former, the contribution due to orographic differences between the LGM ice sheet and the present-day ice sheet is eliminated by the lapse-rate terms. In order to adjust the anomalies to data of the LGM climate, the anomalies are further modified by factors $f_{\mathrm{tma}}, f_{\mathrm{tmj}}$ and $f_{\mathrm{pma}}$ :

$$
\begin{gathered}
\widehat{T}_{\mathrm{ma}}^{*}(\lambda, \phi)=f_{\mathrm{tma}} \widehat{T}_{\mathrm{ma}}(\lambda, \phi), \\
\widehat{T}_{\mathrm{mj}}^{*}(\lambda, \phi)=f_{\mathrm{tmj}} \widehat{T}_{\mathrm{mj}}(\lambda, \phi), \\
\widehat{P}_{\mathrm{ma}}^{*}(\lambda, \phi)=f_{\mathrm{pma}} \widehat{P}_{\mathrm{ma}}(\lambda, \phi) .
\end{gathered}
$$

The factors are chosen as $f_{\mathrm{tma}}=f_{\mathrm{tmj}}=1.9$ and $f_{\mathrm{pma}}=1$. The temperature factors increase the LGM anomaly of the mean annual surface temperature at GRIP from $-12.4^{\circ} \mathrm{C}$ to $-23.4^{\circ} \mathrm{C}$, in agreement with the palaeotemperatures derived by Johnsen and others (1995). The precipitation anomalies at the GRIP, NorthGRIP, Camp Century and Dye 3 ice-core locations are within the range of 0.228 (NorthGRIP) and 0.294 (GRIP), which is consistent with other estimates (Johnsen and others, 1995; Cuffey and Clow, 1997; DahlJensen and others, 2003), so that a modification is not required.

With the above-defined glacial index, the mean annual surface temperature is parameterized by

$$
T_{\text {ma }}(\lambda, \phi, t)=T_{\text {ma, present }}(\lambda, \phi)+g(t) \widehat{T}_{\text {ma }}^{*}(\lambda, \phi),
$$

accordingly for the mean July surface temperature $T_{\mathrm{mj}}(\lambda, \phi, t)$, and the mean annual precipitation rate is computed as

$$
P_{\text {ma }}(\lambda, \phi, t)=P_{\text {ma, present }}(\lambda, \phi) \exp \left[g(t) \ln \widehat{P}_{\text {ma }}^{*}(\lambda, \phi)\right] .
$$

Equations (7) and (8) produce present-day conditions for $g=0$ and LGM conditions for $g=1$ as required. The exponential precipitation interpolation of Equation (8) was chosen because it also fulfils the condition $P_{\mathrm{ma}}(g \rightarrow \infty)=0$ (note that $\ln \widehat{P}_{\text {ma }}^{*}<0$ because $0<\widehat{P}_{\text {ma }}^{*}<1$ ), in other words, the precipitation vanishes at the limit of extremely cold conditions.

Conversion from mean annual precipitation $P_{\text {ma }}$ to snowfall (solid precipitation) is done on a monthly basis with the empirical relation by Marsiat (1994),

$S_{\mathrm{mm}}=P_{\mathrm{ma}} \times \begin{cases}0, & T_{\mathrm{mm}} \geq 7^{\circ} \mathrm{C}, \\ \left(7^{\circ} \mathrm{C}-T_{\mathrm{mm}}\right) / 17^{\circ} \mathrm{C}, & -10^{\circ} \mathrm{C} \leq T_{\mathrm{mm}} \leq 7^{\circ} \mathrm{C}, \\ 1, & T_{\mathrm{mm}} \leq-10^{\circ} \mathrm{C},\end{cases}$

where $S_{\mathrm{mm}}$ is the mean monthly snowfall and $T_{\mathrm{mm}}$ the mean monthly surface temperature computed from $T_{\mathrm{ma}}$ and $T_{\mathrm{mj}}$ by 
assuming a sinusoidal annual cycle. Mean monthly rainfall (liquid precipitation) is obtained as the difference between precipitation and snowfall.

Surface melting is parameterized by Reeh's (1991) degree-day method, supplemented by explicit consideration of rainfall and the semi-analytical solution for the positivedegree-day integral by Calov and Greve (2004). Following Tarasov and Peltier (2002), different degree-day factors for ice melt and snowmelt and for warm $\left(\beta_{\text {ice, }}^{\mathrm{w}}, \beta_{\text {snow }}^{\mathrm{w}}\right)$ and cold $\left(\beta_{\text {ice }}^{\mathrm{c}}, \beta_{\text {snow }}^{\mathrm{c}}\right)$ conditions are introduced. South of $72^{\circ} \mathrm{N}$, it is assumed that warm conditions prevail, so that

$$
\beta_{\text {ice }}=\beta_{\text {ice' }}^{\mathrm{w}} \quad \beta_{\text {snow }}=\beta_{\text {snow }}^{\mathrm{w}} \text {. }
$$

North of $72^{\circ} \mathrm{N}$, the actual degree-day factors are made dependent on the mean July surface temperature $T_{\mathrm{mj}}$,

$$
\beta_{\text {ice }}= \begin{cases}\beta_{\text {ice }}^{\mathrm{w}} & T_{\mathrm{mj}} \geq T_{\mathrm{w},} \\ \beta_{\text {ice }}^{\mathrm{w}}+\frac{\beta_{\mathrm{ice}}^{\mathrm{c}}-\beta_{\mathrm{ice}}^{\mathrm{w}}}{\left(T_{\mathrm{w}}-T_{\mathrm{c}}\right)^{3}}\left(T_{\mathrm{w}}-T_{\mathrm{mj}}\right)^{3} & T_{\mathrm{c}} \leq T_{\mathrm{mj}} \leq T_{\mathrm{w}} \\ \beta_{\text {ice }}^{\mathrm{c}} & T_{\mathrm{mj}} \leq T_{\mathrm{c},}\end{cases}
$$

and

$$
\beta_{\text {snow }}= \begin{cases}\beta_{\text {snow }}^{\mathrm{w}} & T_{\mathrm{mj}} \geq T_{\mathrm{w}} \\ \beta_{\text {snow }}^{\mathrm{c}}+\frac{\beta_{\text {snow }}^{\mathrm{w}}-\beta_{\text {snow }}^{\mathrm{c}}}{T_{\mathrm{w}}-T_{\mathrm{c}}}\left(T_{\mathrm{mj}}-T_{\mathrm{c}}\right) & T_{\mathrm{c}} \leq T_{\mathrm{mj}} \leq T_{\mathrm{w}} \\ \beta_{\text {snow }}^{\mathrm{c}} & T_{\mathrm{mj}} \leq T_{\mathrm{c}}\end{cases}
$$

For the limiting temperatures, the values by Tarasov and Peltier (2002), $T_{\mathrm{w}}=10^{\circ} \mathrm{C}$ and $T_{\mathrm{C}}=-1^{\circ} \mathrm{C}$, are applied, and the limiting degree-day factors are chosen as $\beta_{\text {ice }}^{\mathrm{w}}=$ $7 \mathrm{~mm}$ w.e. $\mathrm{d}^{-1}{ }^{\circ} \mathrm{C}^{-1}, \beta_{\text {ice }}^{\mathrm{c}}=15 \mathrm{~mm}$ w.e. $\mathrm{d}^{-1}{ }^{\circ} \mathrm{C}^{-1}$ and $\beta_{\text {snow }}^{\mathrm{w}}=$ $\beta_{\text {snow }}^{\text {c }}=3 \mathrm{~mm}$ w.e. $\mathrm{d}^{-1}{ }^{\circ} \mathrm{C}^{-1}$. Further, according to Reeh (1991), the saturation factor for the formation of superimposed ice is chosen as $P_{\max }=0.6$, and the standard deviation of short-term, statistical air-temperature fluctuations is set to $\sigma_{\text {stat }}=4.5^{\circ} \mathrm{C}$.

Sea-level forcing $z_{\mathrm{sl}}$, which determines the land area available for glaciation, is derived from the SPECMAP (spectral-mapping project) marine $\delta^{18} \mathrm{O}$ record (Imbrie and others, 1984) converted to global sea level by

$$
z_{\mathrm{sl}}(\mathrm{m})=-34.83\left(\delta^{18} \mathrm{O}[\% 0]+1.93\right) .
$$

This parameterization produces an LGM sea-level minimum of $-130 \mathrm{~m}$ at $19 \mathrm{kyr}$ BP and an Eemian sea-level high of $5.9 \mathrm{~m}$ at 122 kyr BP (see Fig. 2b).

\section{SIMULATION SET-UP}

The model domain covers the entire land area of Greenland and the surrounding sea, projected to a polar stereographic map with standard parallel at $71^{\circ} \mathrm{N}$ and central meridian at $44^{\circ} \mathrm{W}$. Distortions due to this projection are accounted for as metric coefficients in the model equations. Present geometry (surface elevation, bedrock elevation, ice thickness, equilibrated bedrock elevation) is taken from the $5 \mathrm{~km}$ dataset by Bamber and others (2001b, c).

All input data have been resampled to a $20 \mathrm{~km}$ grid, which leads to 82 by 140 gridpoints in the stereographic plane. In the vertical, $\sigma$ coordinates are used, in that the cold-ice column, the temperate-ice layer (if present) and the lithosphere layer are mapped separately to $[0,1]$ intervals. The cold-ice column is then discretized by 81 gridpoints (which densify towards the base), and the temperate-ice and lithosphere layers are each discretized by 11 equidistant gridpoints.

Model time for all simulations is from $250 \mathrm{kyr} B \mathrm{P}$ until today. Initial conditions are provided by spin-up simulations from $422 \mathrm{kyr}$ BP until $250 \mathrm{kyrBP}$ with a quasi-steady-state lithosphere temperature (that is, its vertical gradient is balanced by the geothermal heat flux without any time lag); in other words, the thermal inertia of the lithosphere is switched off during spin-up. The time-step for all model components is 5 years. With these settings, a full simulation (spin-up run and transient run) requires approximately 11 hours CPU time on a $3.4 \mathrm{GHz}$ Pentium-4 PC operated under LINUX.

\section{SIMULATIONS WITH VARIED GEOTHERMAL HEAT FLUX}

\subsection{Run hf_cst: constant heat flux}

The starting point of this study is the assumption of a spatially constant geothermal heat flux of $60 \mathrm{~mW} \mathrm{~m}^{-2}$, which was obtained by matching measured and simulated basal temperatures at GRIP. This value is within the range of the heat fluxes used in previous modelling studies of the Greenland ice sheet (see section 1), and slightly larger than the heat fluxes inferred for the GRIP location by Dahl-Jensen and others (1998) and Tarasov and Peltier (2003). Simulation hf_cst has been run with this value, and the results for the ice thicknesses and basal temperatures for the GRIP, NorthGRIP, Camp Century and Dye 3 ice-core locations are listed in Table 2.

For GRIP, the remaining misfit of the basal temperature is only $0.2^{\circ} \mathrm{C}$, and the adequate choice of the geothermal heat flux is validated by the excellent agreement for the ice thickness (18 m or $0.6 \%$ misfit). Also, at NorthGRIP good agreement is achieved; the simulated and observed basal temperatures are both at the pressure-melting point, and the ice column is $51 \mathrm{~m}(1.7 \%)$ too thin. This good agreement is surprising, because even in the recent study by Tarasov and Peltier (2003) where a very thorough tuning procedure of a similar model was carried out, the basal temperature at NorthGRIP was still $5^{\circ} \mathrm{C}$ below pressure melting. Therefore, the improved representation of the conditions at NorthGRIP in this study is due to the more detailed climatic forcing (section 3), which accounts for the variability of the spatial distribution of precipitation and surface temperature over time. At Camp Century, the simulated temperature is $2.9^{\circ} \mathrm{C}$ too high, and the ice column is $134 \mathrm{~m}(9.7 \%)$ too thin. This indicates that the geothermal heat flux is too large. Dye 3 exhibits the largest disagreement, with a $10.2^{\circ} \mathrm{C}$ too high temperature and a $453 \mathrm{~m}(22.2 \%)$ too thin ice column. This poor agreement, already reported in previous studies (e.g. Huybrechts, 1996), suggests a distinctly lower geothermal heat flux in the southern part of the Greenland ice sheet.

\subsection{Run hf_psc: scaled Pollack and others (1993) heat flux}

The above assumption of a spatially constant geothermal heat flux is very unlikely for an area as large as Greenland. The spherical harmonic representation to degree and order 12 of the global heat flow by Pollack and others (1993) shows a significant horizontal gradient $\left(\sim 25 \mathrm{~mW} \mathrm{~m}^{-2}\right.$ per $1000 \mathrm{~km}$ ) mainly towards the east in the Greenland area. However, the representation is poorly constrained in this 
Table 2. Simulated and observed ice thicknesses and basal temperatures for the GRIP, NorthGRIP, Camp Century and Dye 3 ice-core locations

\begin{tabular}{|c|c|c|c|c|c|c|c|c|}
\hline \multirow[t]{3}{*}{ Simulation } & \multicolumn{2}{|c|}{ GRIP } & \multicolumn{2}{|c|}{ NorthGRIP } & \multicolumn{2}{|c|}{ Camp Century } & \multicolumn{2}{|c|}{ Dye 3} \\
\hline & $H$ & $T_{\mathrm{b}}$ & $H$ & $T_{\mathrm{b}}$ & $H$ & $T_{\mathrm{b}}$ & $H$ & $T_{\mathrm{b}}$ \\
\hline & $\mathrm{km}$ & ${ }^{\circ} \mathrm{C}$ & $\mathrm{km}$ & ${ }^{\circ} \mathrm{C}$ & $\mathrm{km}$ & ${ }^{\circ} \mathrm{C}$ & $\mathrm{km}$ & ${ }^{\circ} \mathrm{C}$ \\
\hline hf_cst & 3.047 & -8.36 & 3.029 & $-2.64^{\star}$ & 1.253 & -10.11 & 1.584 & -3.00 \\
\hline hf_psc & 3.069 & -8.49 & 3.066 & -3.03 & 1.301 & -11.68 & 1.579 & -2.80 \\
\hline hf_pmod1 & 3.065 & -8.42 & 3.045 & $-2.65^{\star}$ & 1.319 & -13.04 & 1.795 & -13.05 \\
\hline hf_pmod2 & 2.949 & -8.33 & 2.937 & $-2.56^{\star}$ & 1.331 & -13.04 & 1.787 & -13.01 \\
\hline Obs. & 3.029 & -8.56 & 3.080 & $-2.4^{\star}$ & 1.387 & -13.00 & 2.037 & -13.22 \\
\hline
\end{tabular}

*Temperature at the pressure-melting point (measured value for NorthGRIP estimated).

Note: Sources: GRIP: Dansgaard and others (1993), Dahl-Jensen and others (1998); NorthGRIP: Dahl-Jensen and others (2003), North Greenland Ice Core Project members (2004); Camp Century: Dansgaard and others (1969), Gundestrup and others (1987, 1993); Dye 3: Gundestrup and Hansen (1984).

region because of the small number of local supporting data, and as already pointed out by Tarasov and Peltier (2003), the heat fluxes are generally too large to provide realistic basal temperatures. Therefore, simulation hf_psc has been run with the heat-flux distribution by Pollack and others (1993), scaled by a constant factor such that the geothermal heat flux at GRIP is reduced to the value $60 \mathrm{~mW} \mathrm{~m}^{-2}$ of run hf_cst. The resulting heat-flux map is shown in Figure 3. Results for the four ice-core locations are summarized in Table 2.

The agreement with observations has not changed significantly compared to simulation hf_cst. It is still excellent at GRIP, not surprisingly since the geothermal heat flux has not been changed at this site. For NorthGRIP,

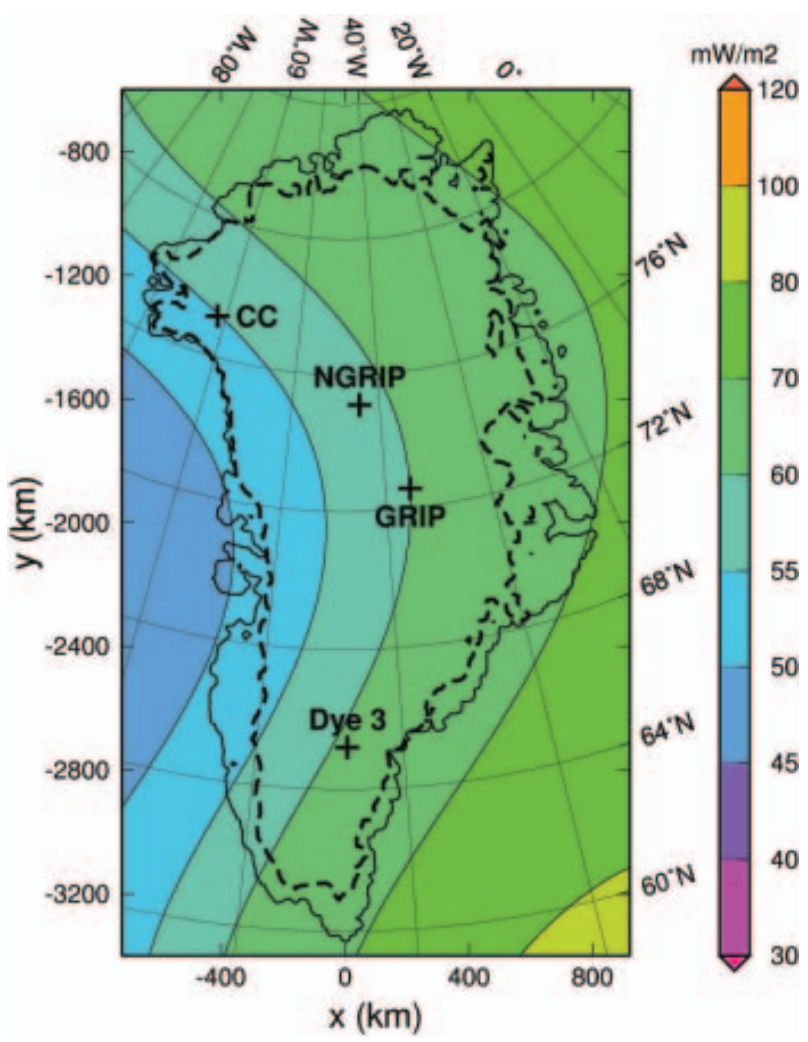

Fig. 3. Distribution of the geothermal heat flux by Pollack and others (1993) scaled to a value of $60 \mathrm{~mW} \mathrm{~m}^{-2}$ at GRIP (for simulation hf_psc). The heavy dashed line indicates the presentday ice margin. the ice thickness fits slightly better and the temperature slightly worse, which indicates that the remaining misfit is not attributable to the geothermal heat flux alone. The agreement at Camp Century has improved distinctly for both the ice thickness and the basal temperature, which is a clear consequence of the reduced geothermal heat flux in the area. For Dye 3, the results are very similar to those of simulation hf_cst, so that the large misfit remains.

\subsection{Runs hf_pmod1/2: modified Pollack and others (1993) heat flux}

To achieve better agreement between measured and modelled basal temperatures and ice thicknesses, the aboveconstructed geothermal-heat-flux map is modified as follows. For the $N_{\mathrm{m}}=444$ margin points of the numerical domain, $\left(x_{n}, y_{n}\right), n=1 \ldots N_{\mathrm{m}}$, the geothermal heat fluxes $q_{\mathrm{geo}, n}$ of the above procedure are kept. For the $N_{\mathrm{c}}=4$ icecore locations $\left(x_{n}, y_{n}\right), n=N_{m}+1 \ldots N_{m}+N_{c}$ (GRIP, NorthGRIP, Camp Century, Dye 3), the geothermal heat fluxes $q_{\mathrm{geo}, n}$ are chosen such that the simulated basal temperatures match the modelled ones. With these $N=N_{m}+N_{c}=448$ reference points, the new geothermal-heat-flux distribution $q_{g e o}(x, y)$ is computed by the weighed interpolation

$$
q_{\mathrm{geo}}(x, y)=\frac{\sum_{n=1}^{N} w_{n}(x, y) q_{\mathrm{geo}, n}}{\sum_{n=1}^{N} w_{n}(x, y)} .
$$

The weighing factors $w_{n}$ are taken as the squares of the inverse distances from the arbitrary position $(x, y)$ to the reference points $\left(x_{n}, y_{n}\right)$,

$W_{n}(x, y)=\left\{\begin{array}{lll}\frac{1}{N_{\mathrm{m}}} \frac{1}{\left(x-x_{n}\right)^{2}+\left(y-y_{n}\right)^{2}}, & n \leq N_{\mathrm{m}} & \text { (margin point), } \\ \frac{1}{N_{\mathrm{c}} \frac{1}{\left(x-x_{n}\right)^{2}+\left(y-y_{n}\right)^{2}},} & n>N_{\mathrm{m}} & \text { (ice-core point). }\end{array}\right.$

The additional factors $1 / N_{m}$ and $1 / N_{c}$, respectively, have been introduced in order to provide a balance between the influence of the large number of margin points and the small number of ice-core locations.

The basal melting conditions at NorthGRIP make the matching procedure of basal temperatures non-unique there. Only the minimum heat flux required to produce pressure melting is well defined; any further increase leads merely to increased basal melting. Therefore, two different 

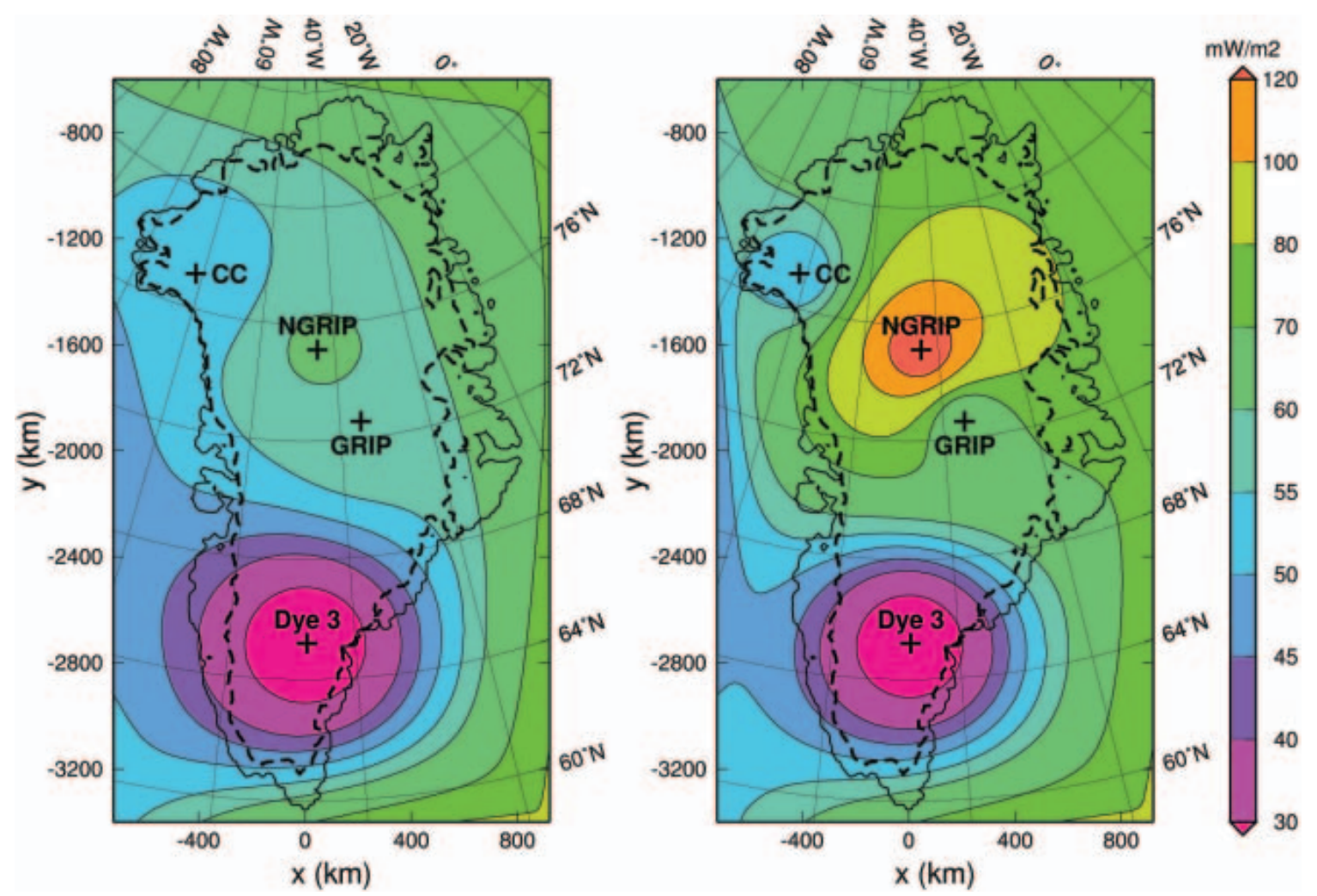

Fig. 4. Distributions of the geothermal heat flux based on Pollack and others (1993), modified with the values of Equation (16) for GRIP, NorthGRIP, Camp Century and Dye 3, for simulations hf_pmod1 (left) and hf_pmod2 (right). The heavy dashed lines indicate the present-day ice margin.

matching procedures are carried out, (i) with the minimum heat flux at NorthGRIP, and (ii) with the heat flux that produces the basal melting rate of $77 \mathrm{~mm}$ ice equiv. $\mathrm{a}^{-1}$ reported by Dahl-Jensen and others (2003). This yields the following set of values (left/right values correspond to procedures (i) and (ii), respectively):

$$
\begin{aligned}
\text { GRIP: } q_{\text {geo }} & =60 / 60 \mathrm{~mW} \mathrm{~m}^{-2}, \\
\text { NorthGRIP: } q_{\text {geo }} & =61 / 135 \mathrm{~mW} \mathrm{~m}^{-2}, \\
\text { Camp Century: } q_{\text {geo }} & =52 / 50 \mathrm{~mW} \mathrm{~m}^{-2}, \\
\text { Dye } 3: q_{\text {geo }} & =20 / 20 \mathrm{~mW} \mathrm{~m}^{-2} .
\end{aligned}
$$

Figure 4 depicts the modified maps of the geothermal heat flux. The influence of the very different heat fluxes at NorthGRIP is most pronounced in the northeastern sector of Greenland. Table 2 displays the results of the corresponding simulations hf_pmod1 (procedure (i)) and hf_pmod2 (procedure (ii)) for the four ice-core locations.

Evidently, for both simulations the basal temperatures at the four ice-core locations are matched within $\sim 0.2^{\circ} \mathrm{C}$. For simulation hf_pmod1, the resulting ice thicknesses are $1.2 \%$ too large at GRIP, $1.1 \%$ too small at NorthGRIP, $4.9 \%$ too small at Camp Century and $11.9 \%$ too small at Dye 3 . By contrast, for simulation hf_pmod2 all thicknesses are too small, at GRIP by $2.6 \%$, at NorthGRIP by $4.6 \%$, at Camp Century by $4.0 \%$ and at Dye 3 by $12.3 \%$. However, Figure 5 , which displays the simulated surface topography and the ice-thickness misfit for run hf_pmod2, shows that this is not a systematic misfit: in other regions of the ice sheet the simulated thicknesses are too large. Since the heat flux at NorthGRIP used for simulation hf_pmod2 also produces a close match of the simulated basal melting rate $(7.06 \mathrm{~mm}$ ice equiv. $\mathrm{a}^{-1}$ ) to the above-mentioned estimate by Dahl-Jensen and others (2003) and North Greenland Ice Core Project members (2004) (whereas it is $<0.1 \mathrm{~mm}$ ice equiv. $\mathrm{a}^{-1}$ for simulation hf_pmod1), we consider simulation hf_pmod2 (and the corresponding heat-flux distribution of Figure 4, right panel) as more realistic and limit the following discussion to it.

Figure 6 shows the homologous basal temperature computed with simulation hf_pmod2. The large geothermal heat fluxes around NorthGRIP and in the entire northeastern sector of the ice sheet lead to widespread pressure-melting conditions at the ice base. Basal melting also prevails in West Greenland in a wide flowband upstream of Jakobshavn Isbræ where the heat fluxes are lower. Naturally, the anomaly of very low heat fluxes around Dye 3 entails low basal temperatures in the central part of south Greenland.

The small value of $20 \mathrm{~mW} \mathrm{~m}^{-2}$ for the geothermal heat flux at Dye 3 found here (Equation (16)) is corroborated by the temperature profile published in Dahl-Jensen and others (1998) (the gradient at the base corresponds to a heat flow of $\sim 25 \mathrm{~mW} \mathrm{~m}^{-2}$ into the ice body) and the findings by Huybrechts (1996) who reports that in his reference run $0.44 \mathrm{HFU}$ (heat-flow units) $=18.5 \mathrm{~mW} \mathrm{~m}^{-2}$ are required to match the observed basal temperature. However, Figure 5 shows that the south dome of the ice sheet is situated too far west, and that the eastern part of the ice sheet south of $67^{\circ} \mathrm{N}$ is generally too thin by $200-500 \mathrm{~m}$. This explains the significant ice-thickness misfit at Dye 3. The discrepancy is likely due to too low precipitation rates over the southeastern ice sheet.

Figure 7 shows the evolution of the ice volume and the ice-covered area over the last $150 \mathrm{kyr}$. As expected, both 

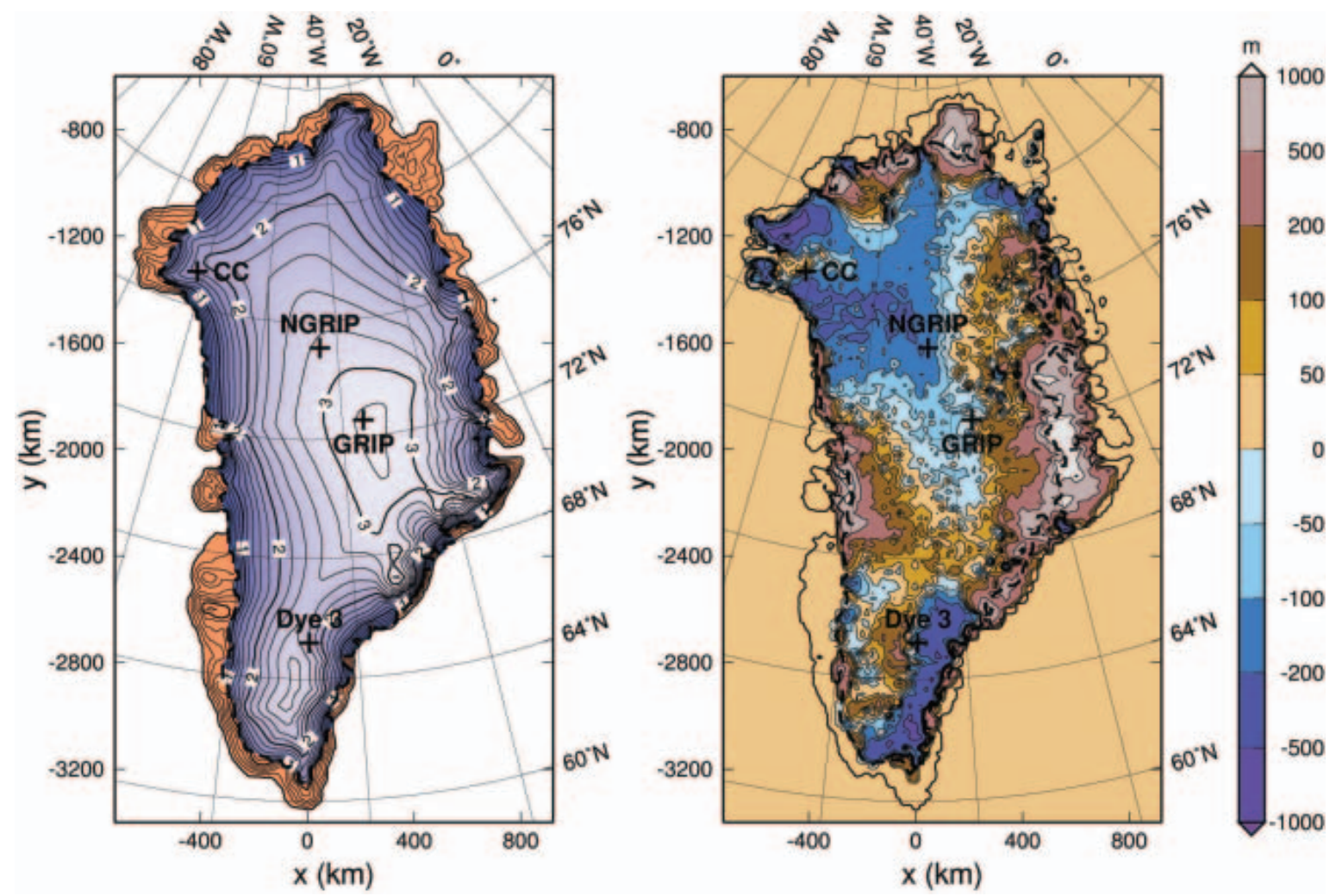

Fig. 5. Simulation hf_pmod2: present-day surface topography (left panel; contour spacing $200 \mathrm{~m}$, labels in km a.s.I.), and difference between simulated and observed present-day ice thickness (right panel). The heavy dashed lines indicate the simulated (left panel) and observed (right panel) ice margins.

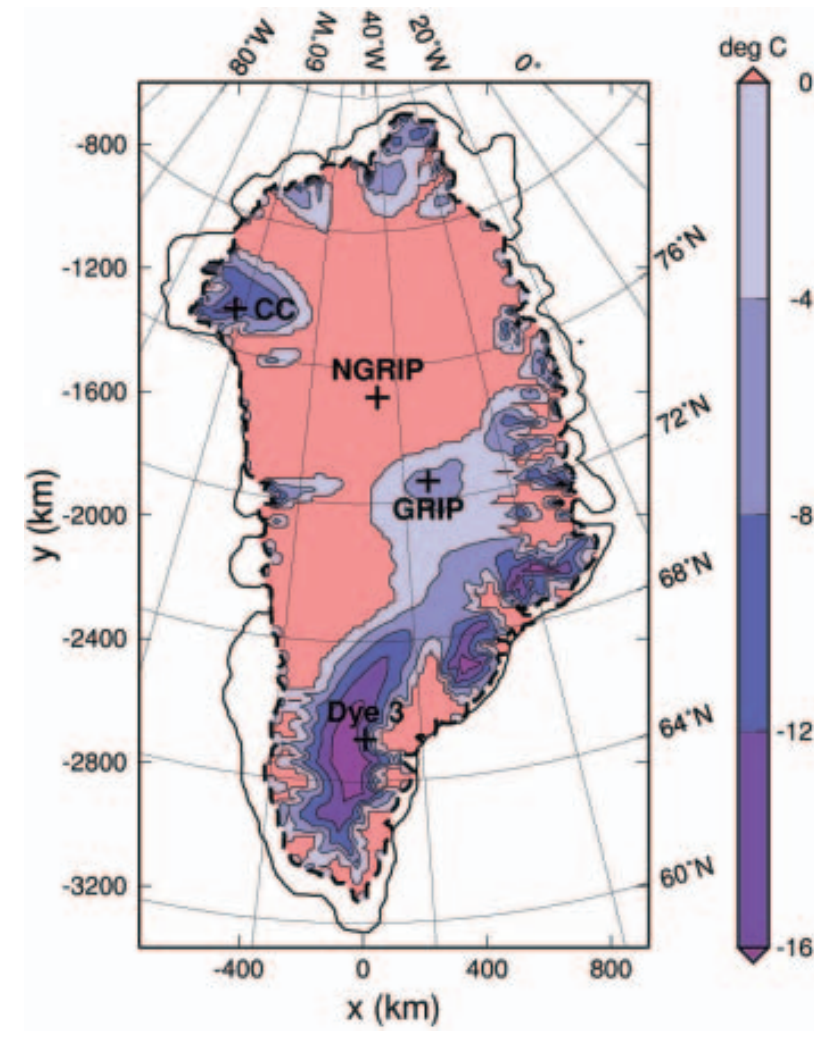

Fig. 6. Simulation hf_pmod2: present-day basal homologous temperature (temperature relative to pressure melting). Red areas are at the pressure-melting point. The heavy dashed line indicates the simulated ice margin.
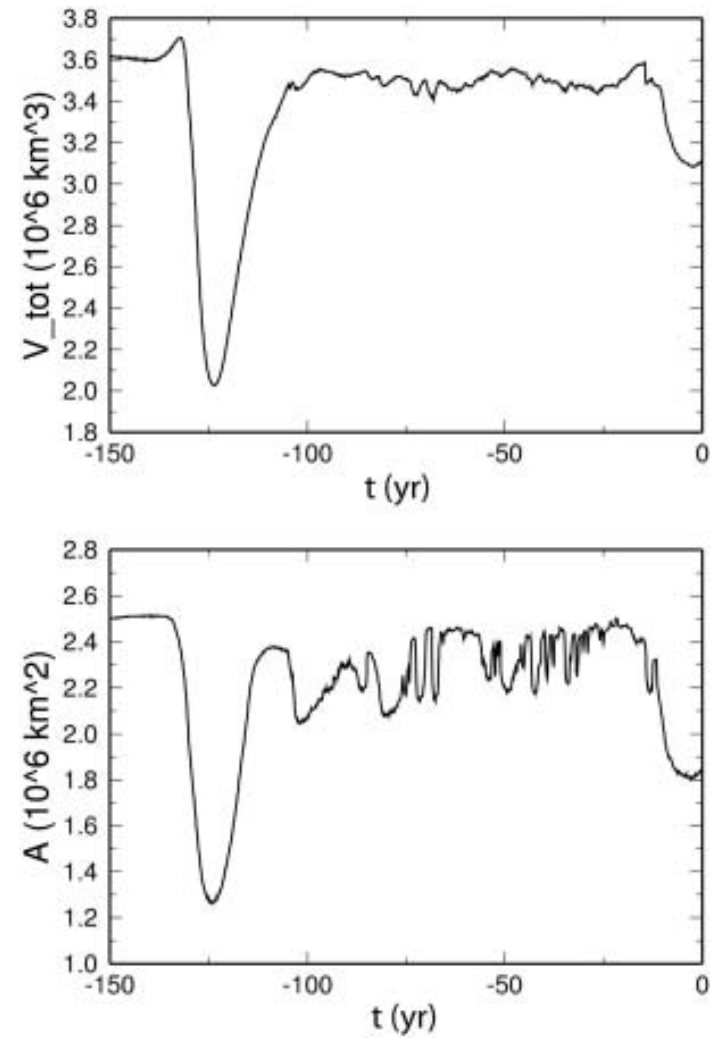

Fig. 7. Simulation hf_pmod2: evolution of the ice volume $V_{\text {tot }}$ and the ice-covered area $A$ over the last $150 \mathrm{kyr}$. 
quantities are larger during glacial and smaller during interglacial periods, and the Eemian ice retreat is much more pronounced than the retreat during the Holocene. The simulated Eemian ice-volume minimum at $123.5 \mathrm{kyr} \mathrm{BP}$ $\left(2.026 \times 10^{6} \mathrm{~km}^{3}\right)$ corresponds to an equivalent sea-level rise of $2.75 \mathrm{~m}$ compared to the simulated present-day volume $\left(3.115 \times 10^{6} \mathrm{~km}^{3}\right)$. The LGM ice volume at $21 \mathrm{kyr} \mathrm{BP}$ is $3.487 \times 10^{6} \mathrm{~km}^{3}$ or $0.94 \mathrm{~m}$ of sea-level lowering. Note that values for sea-level equivalents are based on the ratio $7.2 / 2.85=2.5263 \mathrm{~m}$ s.l.e. per $10^{6} \mathrm{~km}^{3}$ ice volume, which was reported for the Greenland ice sheet by Church and others (2001, table 11.3).

The sea-level equivalent of the simulated present-day ice volume is $7.87 \mathrm{~m}, 6.2 \%$ more than the $7.41 \mathrm{~m}$ which correspond to the observed volume of $2.932 \times 10^{6} \mathrm{~km}^{3}$. As can be inferred from Figure 5 (right panel), most of this difference originates from simulated ice cover in areas where there is no ice in reality. In Peary Land, north of $82^{\circ} \mathrm{N}$, the simulation predicts an ice tongue which has no real counterpart, and similarly the almost ice-free area east of $30^{\circ} \mathrm{W}$, between $68^{\circ} \mathrm{N}$ and $74^{\circ} \mathrm{N}$, remains glacierized in the simulation result. These deficiencies are most likely due to inaccuracies in the mass-balance forcing.

\section{CONCLUSION}

The thermomechanical ice-sheet model SICOPOLIS was applied to the Greenland ice sheet, and simulations were carried out over two glacial-interglacial cycles, driven by a climatic forcing interpolated between present conditions and LGM anomalies on the basis of a glacial index derived from the GRIP $\delta^{18} \mathrm{O}$ and the Vostok $\delta \mathrm{D}$ record. Four different distributions of the geothermal heat flux were employed: a constant value for the entire ice sheet, a scaled Pollack and others (1993) heat-flux distribution, and two different heatflux maps assembled by modifying the latter with prescribed values for the GRIP, NorthGRIP, Camp Century and Dye 3 ice-core locations.

It was demonstrated that with the modified Pollack and others (1993) map shown in Figure 4 (right panel) an excellent match is achieved for the basal temperatures of the four ice cores, including the estimated basal melting rate at NorthGRIP. This heat-flux map still shows the increasing trend from west to east of the original Pollack and others (1993) distribution. The most prominent overlying structures are the high-heat-flux anomaly around NorthGRIP with values up to $135 \mathrm{~mW} \mathrm{~m}^{-2}$, and the low-heat-flux anomaly around Dye 3 with values down to $20 \mathrm{~mW} \mathrm{~m}^{-2}$. However, since the interpolation of the geothermal heat flux in the interior of Greenland is only based on the four boreholes, it is very likely that the spatial variation is much larger in reality. This notion is supported by Fahnestock and others (2001), who used data from airborne ice-penetrating radar and inferred highly varying basal melting rates in the northeastern sector of the Greenland ice sheet which correspond to local heat fluxes as high as 15-30 times average values.

The ice thickness, which was used for validating the simulation results, shows a good agreement for GRIP, NorthGRIP and Camp Century, but there is a significant misfit of $>12 \%$ for Dye 3 which originates from a shift of the simulated with respect to the observed south dome. This discrepancy, other inaccuracies of the simulated ice thick- ness and the failure of the simulation to reproduce the observed ice margin in the far north and in parts of East Greenland, are most likely due to the above-mentioned further variability of the geothermal heat flux as well as deficiencies of the input precipitation rate. Therefore, the importance for improving the mass-balance input is underlined. In future work, alternative precipitation data like the map assembled as part of the PARCA (Program for Arctic Regional Climate Assessment) project (Bales and others, 2001) will be considered. It may also be helpful to compare the output of different GCM simulations for defining LGM anomalies. However, in the long term the most promising approach is to overcome the problem of mass-balance input by conducting coupled simulations with atmosphere and ice-sheet models.

\section{ACKNOWLEDGEMENTS}

I thank P. Calanca for kindly sending the digitized accumulation data for the Greenland ice sheet. The $5 \mathrm{~km}$ DEM, icethickness and bedrock elevation data were provided by the US National Snow and Ice Data Center (NSIDC), University of Colorado, Boulder, CO. The help of J. Bamber in implementing these data is gratefully acknowledged. The comments of the two referees, P. Huybrechts and S.J. Johnsen, and the scientific editor D. Dahl-Jensen have helped considerably to improve this paper.

\section{REFERENCES}

Bales, R.C., J.R. McConnell, E. Mosley-Thompson and B. Csathó. 2001. Accumulation over the Greenland ice sheet from historical and recent records. J. Geophys. Res., 106(D24), 33,813-33,825.

Bamber, J.L. and P. Huybrechts. 1996. Geometric boundary conditions for modelling the velocity field of the Antarctic ice sheet. Ann. Glaciol., 23, 364-373.

Bamber, J.L., S. Ekholm and W.B. Krabill. 2001a. A new, highresolution digital elevation model of Greenland fully validated with airborne laser altimeter data. J. Geophys. Res., 106(B4), 6733-6746.

Bamber, J.L., R.L. Layberry and S.P. Gogineni. 2001b. A new ice thickness and bed data set for the Greenland ice sheet. 1. Measurement, data reduction, and errors. J. Geophys. Res., 106(D24), 33,773-33,780.

Bamber, J.L., R.L. Layberry and S.P. Gogineni. 2001c. A new ice thickness and bed data set for the Greenland ice sheet. 2. Relationship between dynamics and basal topography. J. Geophys. Res., 106(D24), 33,781-33,788.

Calov, R. and R. Greve. 2004. Correspondence. A semi-analytical solution for the positive degree-day model with stochastic temperature variations. J. Glaciol., 51(172), 173-175.

Calov, R. and K. Hutter. 1996. The thermomechanical response of the Greenland ice sheet to various climate scenarios. Climate Dyn., 12(4), 243-260.

Church, J.A. and 7 others. 2001. Changes in sea level. In Houghton, J.T. and 7 others, eds. Climate change 2001: the scientific basis. Contribution of Working Group I to the Third Assessment Report of the Intergovernmental Panel on Climate Change. Cambridge, etc., Cambridge University Press, 639-693.

Cuffey, K.M. and G.D. Clow. 1997. Temperature, accumulation, and ice sheet elevation in central Greenland through the last deglacial transition. J. Geophys. Res., 102(C12), 26,383-26,396.

Dahl-Jensen, D. and 6 others. 1998. Past temperatures directly from the Greenland ice sheet. Science, 282(5387), 268-271.

Dahl-Jensen, D., N. Gundestrup, S.P. Gogineni and H. Miller. 2003. Basal melt at NorthGRIP modeled from borehole, ice-core and radio-echo sounder observations. Ann. Glaciol., 37, 207-212. 
Dansgaard, W., S.J. Johnsen, J. Møller and C.C. Langway, Jr. 1969. One thousand centuries of climatic record from Camp Century on the Greenland ice sheet. Science, 166(3903), 377-381.

Dansgaard, W. and 10 others. 1993. Evidence for general instability of past climate from a 250-kyr ice-core record. Nature, 364(6434), 218-220.

Fahnestock, M., W. Abdalati, I. Joughin, J. Brozena and P. Gogineni. 2001. High geothermal heat flow, basal melt, and the origin of rapid ice flow in central Greenland. Science, 294(5550), 2338-2342.

Forsström, P.-L. and R. Greve. 2004. Simulation of the Eurasian ice sheet dynamics during the last glaciation. Global Planet. Change, 42(1-4), 59-81.

Forsström, P.L., O. Sallasmaa, R. Greve and T. Zwinger. 2003. Simulation of fast-flow features of the Fennoscandian ice sheet during the Last Glacial Maximum. Ann. Glaciol., 37, 383-389.

Greve, R. 1997. Application of a polythermal three-dimensional ice sheet model to the Greenland ice sheet: response to steady-state and transient climate scenarios. J. Climate, 10(5), 901-918.

Greve, R. 2001. Glacial isostasy: models for the response of the Earth to varying ice loads. In Straughan, B., R. Greve, $\mathrm{H}$. Ehrentraut and Y. Wang, eds. Continuum mechanics and applications in geophysics and the environment. Berlin, etc., Springer-Verlag, 307-325.

Greve, R. and K. Hutter. 1995. Polythermal three-dimensional modelling of the Greenland ice sheet with varied geothermal heat flux. Ann. Glaciol., 21, 8-12.

Greve, R., M. Weis and K. Hutter. 1998. Palaeoclimatic evolution and present conditions of the Greenland ice sheet in the vicinity of Summit: an approach by large-scale modelling. Palaeoclimates: Data and Modelling, 2(2-3), 133-161.

Greve, R., B. Mügge, D. Baral, O. Albrecht and A. Savvin. 1999. Nested high-resolution modelling of the Greenland Summit region. In Hutter, K., Y. Wang and $\mathrm{H}$. Beer, eds. Advances in cold-region thermal engineering and sciences: technological, environmental, and climatological impact. Berlin, etc., SpringerVerlag, 285-306. (Lecture Notes in Physics 533.)

Gundestrup, N.S. and B.L. Hansen. 1984. Bore-hole survey at Dye 3, south Greenland. J. Glaciol., 30(106), 282-288.

Gundestrup, N.S., H.B. Clausen, B.L. Hansen and J. Rand. 1987. Camp Century survey 1986. Cold Reg. Sci. Technol., 14(3), 281-288.

Gundestrup, N.S., D. Dahl-Jensen, B.L. Hansen and J. Kelty. 1993. Bore-hole survey at Camp Century, 1989. Cold Reg. Sci. Technol., 21(2), 187-193.

Hewitt, C.D. and J.F.B. Mitchell. 1997. Radiative forcing and response of a GCM to ice age boundary conditions: cloud feedback, and climate sensitivity. Climate Dyn., 13(11), 821-834.

Hindmarsh, R.C.A. and E. Le Meur. 2001. Dynamical processes involved in the retreat of marine ice sheets. J. Glaciol., 47(157), 271-282.

Hutter, K. 1983. Theoretical glaciology; material science of ice and the mechanics of glaciers and ice sheets, Dordrecht, etc., D. Reidel Publishing Co.; Tokyo, Terra Scientific Publishing Co.

Huybrechts, P. 1996. Basal temperature conditions of the Greenland ice sheet during the glacial cycles. Ann. Glaciol., 23, 226-236.

Huybrechts, P. 2002. Sea-level changes at the LGM from icedynamic reconstructions of the Greenland and Antarctic ice sheets during the glacial cycles. Quat. Sci. Rev., 21(1-3), 203-231.

Imbrie, J. and 8 others. 1984. The orbital theory of Pleistocene climate: support from a revised chronology of the marine $\delta^{18} \mathrm{O}$ record. In Berger, A., J. Imbrie, J. Hays, G. Kukla and B. Saltzman, eds. Milankovitch and climate: understanding the response to astronomical forcing. Part 1. Dordrecht, etc., D. Reidel Publishing Co., 269-305. (NATO ASI Series C: Mathematical and Physical Sciences 126.)

Jaeger, L. 1976. Monatskarten des Niederschlags für die ganze Erde. Berichte des Deutschen Wetterdienstes, 18(139), 1-38.

Johnsen, S.J., D. Dahl-Jensen, W. Dansgaard and N.S. Gundestrup. 1995. Greenland paleotemperatures derived from GRIP borehole temperature and ice core isotope profiles. Tellus, 47B(5), 624-629.

Le Meur, E. and P. Huybrechts. 1996. A comparison of different ways of dealing with isostasy: examples from modelling the Antarctic ice sheet during the last glacial cycle. Ann. Glaciol. 23, 309-317.

Letréguilly, A., N. Reeh and P. Huybrechts. 1991. The Greenland ice sheet through the last glacial-interglacial cycle. Palaeogeogr., Palaeoclimatol., Palaeoecol., 90(4), 385-394.

Marshall, S.J. and K.M. Cuffey. 2000. Peregrinations of the Greenland ice sheet divide in the last glacial cycle: implications for central Greenland ice cores. Earth Planet. Sci. Lett., 179(1), 73-90.

Marsiat, I. 1994. Simulation of the Northern Hemisphere continental ice sheets over the last glacial-interglacial cycle: experiments with a latitude-longitude vertically integrated ice sheet model coupled to a zonally averaged climate model. Palaeoclimates: Data and Modelling, 1(1), 59-98.

Morland, L.W. 1984. Thermomechanical balances of ice sheet flows. Geophys. Astrophys. Fluid Dyn., 29, 237-266.

North Greenland Ice Core Project members. 2004. High-resolution record of Northern Hemisphere climate extending into the last interglacial period. Nature, 431(7005), 147-151.

Paterson, W.S.B. 1994. The physics of glaciers. Third edition. Oxford, etc., Elsevier.

Petit, J.R. and 18 others. 1999. Climate and atmospheric history of the past 420,000 years from the Vostok ice core, Antarctica. Nature, 399(6735), 429-436.

Pollack, H.N., S.J. Hurter and J.R. Johnson. 1993. Heat flow from the Earth's interior: analysis of the global data set. Rev. Geophys., 31(3), 267-280.

Reeh, N. 1991. Parameterization of melt rate and surface temperature on the Greenland ice sheet. Polarforschung, 59(3), 113-128.

Ritz, C., A. Fabre and A. Letréguilly. 1997. Sensitivity of a Greenland ice sheet model to ice flow and ablation parameters: consequences for the evolution through the last glacial cycle. Climate Dyn., 13(1), 11-24.

Tarasov, L. and W.R. Peltier. 2002. Greenland glacial history and local geodynamic consequences. Geophys. J. Int., 150(1), 198-229.

Tarasov, L. and W.R. Peltier. 2003. Greenland glacial history, borehole constraints, and Eemian extent. J. Geophys. Res. 108(B3), 2143. (10.1029/2001JB001731.)

Thomas, R.H., B.M. Csathó, S. Gogineni, K.C. Jezek and K. Kuivinen. 1998. Thickening of the western part of the Greenland ice sheet. J. Glaciol., 44(148), 653-658.

Van de Wal, R.S.W. 1999. Processes of buildup and retreat of the Greenland ice sheet. J. Geophys. Res., 104(D4), 3899-3906. 